\title{
Determining of Mosque Worshipers Caring to Ward Fatwa of MUI in Preventing Covid-19 in Boja, Kendal District
}

\author{
Rosidin $^{1}$, Arnis Rachmadhani ${ }^{2}$, Samidi $^{3}$, Lilam Kadarin Nuriyanto ${ }^{4}$ \\ ${ }_{1,2,3,4}$ Research and Development Center for Religion Semarang \\ 1nazalnifa@yahoo.co.id, ${ }^{2}$ arnisuksw@ yahoo.co.id, ${ }^{3}$ semedhi99 @ gmail.com, ${ }^{4}$ lilam.ltbg@gmail.com
}

\begin{abstract}
The end of 2019 was marked by the business of humankind in this hemisphere. All countries are focused on fighting against Corona Virus Disease 2019 (Covid-19) after WHO declared a Pandemic. It is also in Indonesia, from rescuing citizens abroad as effort to prevent the spread of this virus. All forces were mobilized, including the MUI religious institution. MUI contributed to preventing Covid-19 by calling on Muslims through MUI Fatwa No. 14 of 2020 concerning the Implementation of Worship in a Situation of the Covid-19 Outbreak. This article seeks to reveal how the caring of the mosque worshipers as the target of this Fatwa is carried out in daily worship. The quantitative approach of this study attempts to capture the determinants of the ummah in urban and rural areas of the Boja Kendal sub-district, from 18 Jami 'mosques in 18 villages, Boja sub-district. The population was taken from the worshipers of 10 mosques consisting of 5 urban mosques and 5 rural mosques. With the assumption of 40 active worshipers, the population will be 400 worshipers. The Kirtji-Morgan table shows a sample of at least 196 respondents, and this study uses data from 200 respondents. The results showed that the level of caring of the mosque worshipers towards the MUI fatwa was 3.27 (very care). This figure comes from 5 aspects of caring, namely the aspect of understanding others at 3.30 (very good), the aspect of feeling at 3.30 (very good), the aspect of doing something for others at 3.17 (care), the aspect of giving support for 3.34 (very caring) and aspects of supporting the spirit of others by 3.25 (care). The determinants of urban mosque worshiperscaring are 3.54 (very care) and rural areas are 3.00 (care). The contribution of understanding aspect of other people in urban are 3.64 (very care) and rural areas are 2.96 (very care), the aspect of feeling also contributes 3.51 (very care) for urban and 3.09 (care) for rural, the aspect of doing something for others, it scores 3.52 (very care) for urban and 2.81 (cares) for rural, then the value is 3.49 (very caring) urban and 3.18 (cares) the aspect of providing support, and the aspect of supporting people's enthusiasm others show a value of 3.54 (very care) for urban areas and a value of 2.96 (care) for members of rural mosques. Thus the concern of mosque worshipers in urban areas is higher than mosque worshipers in rural areas.
\end{abstract}

Keywords

Determinants, Caring, Covid -19, Fatwa of MUI and Mosque Worshipers

Article Received: 10 August 2020, Revised: 25 October 2020, Accepted: 18 November 2020

\section{Introduction}

The World Health Organization (WHO) has declared Corona Virus Disease 2019 (Covid-19) a pandemic. The spread of COVID-19 in Indonesia is now increasingly widespread across regions and across countries accompanied by an increase in the number of cases and / or the number of deaths. This situation is increasingly having an impact on the political, economic, social, cultural, defense and security aspects, as well as the welfare of the people in Indonesia, so a comprehensive strategy and efforts are needed to accelerate the handling of COVID-19 (KMK Document No. HK.01.07 / MENKES / 328) / 2020). The Indonesian government has established a Public Health Emergency for Corona Virus Disease 2019 (COVID-19) in Indonesia, which requires countermeasures in accordance with the provisions of laws and regulations (Doc. KepPres No.11 of 2020).
The government has also designated the NonNatural Disaster for the Spread of COVID-19 as a National Disaster, which states that national disaster management caused by the spread of Corona Virus Disease 2019 (COVID-19) is carried out by the Task Force for the Acceleration of Handling Corona Virus Disease 2019 (COVID19) and the Governor, regents and mayors as Chairpersons of the Task Force for the Acceleration of Handling Corona Virus Disease 2019 (COVID-I9) in the regions and in determining policies in their respective regions must pay attention to Central Government policies (Presidential Decree Number 12 of 2020).

COVID-19 has become a national disaster because of its wide impact. In Antara news, Sunday, May 3, 2020, the Spokesperson for the Handling of COVID-19 Achmad Yurianto, stated that the government has set the COVID-19 
pandemic to be a national disaster because it does not only affect health but is broader.

"The COVID-19 pandemic also has an impact on social, economic, educational, and public order aspects that have the potential to threaten state security if not managed properly," (Yurianto, during a press conference as broadcast on the BNPB Indonesia Youtube account, Sunday, May 3, 2020 )

Determination of the status of a national disaster against a pandemic means that the handling of COVID-19 must be carried out in a guided manner by the government, namely through the Task Force for the Acceleration of Handling COVID-19 at the central and regional levels. Determination of this disaster is a firm policy that requires all elements of government, all elements of the business world, and all elements of society to unite, work hand in hand, and work together in an integrated, coordinated and collaborative system. The key to handling COVID-19 remains on the discipline of all parties to comply with the government's advice to stay at home, not go home, not travel, use a mask when forced to leave the house, and maintain a distance. (Dewanto Samodro and Endang Sukarelawati, copyrigth (C) Antara 2020 , https://www.antaranews.com/berita/1462407/jubi r-pemerintah-covid-19-jadi bencana-nasionalkarena-berdampak-luas, accessed on $27 \mathrm{Mei}$ 2020)

This pandemic has targeted various countries and has had a major impact on all aspects of life. In fact, China, which in his speech for the anniversary of China's Independence Day in October 2019, the President of China stated that there would be no nation in the world that could hinder the progress of the Chinese state, turned out to be collapsed and as the country where the virus started to spread (Suara Hidayatullah, March 2020).

The development of covid-19 is very fast due to its spread through social interactions in human life which are indeed difficult to avoid. The condition of the case in Indonesia is based on the Government as conveyed by the Spokesperson for the Handling of Covid-19 Achmad Yurianto during a press conference at Graha BNPB,
Jakarta. reported by kompas.com, cases of Covid19 in Indonesia until Tuesday (26/5/2020) increased to 23,165 cases.

"415 people were confirmed positive for Covid-19 to 23,165 ," said Yuri, Tuesday. It is known that the total number of positive patients on Monday $(25 / 5 / 2020)$ was 22,750 people. From a total of 23,165 cases, 1,418 patients died. Meanwhile, the number of patients who were declared cured was 5,877 people. The number of patients recovered was obtained from the addition of the last 24 hours, namely 235 patients (https://nasional.kompas.com/read/2020/05/26/15 584581/update-26-mei-tambah-415-pasien-covid19-di-indonesia-jadi-23165-orang,, accessed on 27 May 2020).

The condition of the cases in Central Java Province was stated by the Government as reported by news.detik.com that the Central Java Provincial Government updated the data on cases of the Corona virus or COVID-19 in its region until today (27 May 2020) there are 1,379 positive cases.

website corona.jatengprov.go.id, Wednesday $(27 / 5 / 2020)$ at $10: 29 \mathrm{WIB}$, of the 1,379 cases consisting of 577 people being treated (41.84 percent), 711 people recovered (51, 56 percent) and 91 people died (6.6 percent). When compared with yesterday's data, there were an additional 28 positive cases of the Corona virus in Central Java and 23 cases of Corona patients recovered. The number of Corona patients who died in Central Java also increased by 1 person. The hospitals that are currently treating the most positive patients with the Corona virus are in Magelang Regency with 57 patients, 51 patients at the Dr. Tjitrowardojo Purworejo Regional Hospital, 34 in Semarang City, and 28 Djoyonegoro Hospital, Temanggung. Meanwhile, the most recovered patients included 131 patients at DrKariadi Hospital Semarang, 34 patients at RSUD K.R.M.T Wongsonegoro Semarang, and 33 at DrMoewardi Hospital Solo. In addition, the distribution of cases of Corona patients who died included 16 patients at DrKariadi Semarang Hospital, 14 at DrMoewardi Solo Hospital, and 8 K.R.M.T Wongsonegoro Hospital in Semarang. 
The Central Java Provincial Government also revealed the number of cases of patients under surveillance (PDP) of the Corona virus in its area to date there are 5,237 people. Consisting of 668 people treated (12.76 percent), 3,837 recovered (73.27 percent) and 732 died (13.98 percent). When compared with yesterday's data, there were an increase in the number of PDP Corona virus cases in Central Java by 111 cases. The number of PDP who died also increased by 25 compared to yesterday. Meanwhile, the number of cases of people under surveillance (ODP) of the Corona virus in Central Java today was recorded at 34,941 people. It consists of 1,383 ODPs still under monitoring (3.96 percent) and 33,558 completed monitoring (96.04 percent). When compared to yesterday's data, there were an additional 302 cases of Corona virus ODP in Central Java. (sip/mbr, https://news.detik.com/berita-jawatengah/d-5030015/update-corona-di-jateng-27mei-1379-positif-dan-732-pdp-meninggal, accessed on 27 May 2020).

The spread of Covid 19, which is increasingly widespread, requires comprehensive handling from all institutions at various levels. Both government and society. Both religious and other institutions. One of the religious institutions that anticipated the spread of Covid 19 was the Indonesian Ulama Council (MUI) with the issuance of the Fatwa of the Indonesian Ulama Council Number 14 of 2020 caring the Implementation of Worship in a Situation of the Covid-19 Outbreak on 21 Rajab $1441 \mathrm{H}$ to coincide with March 16, 2020.

MUI is a forum for Muslim scholars, $z u^{\prime} a m a$ and intellectuals who have a structure down to the sub-district level, so it is very reasonable and will be effective in reducing this epidemic. The views of Muslims differ on the MUI fatwa. This is because the content of the fatwa is closely related to worship which is a daily Muslim ritual. The understanding and caring for following the MUI Fatwa varies from one Muslim to another. The issue of caring that arises is the determinant of Muslim caring for the content of the MUI fatwa in urban and rural environments.

This article aims to capture the concern of Muslims in a sub-district in Kendal Regency, to be precise, Boja District. This portrait attempts to describe the index of caring of the mosque worshipers towards the MUI fatwa as well as the determinants of the index of the mosque worshipers in rural areas and urban nuances in this region. The hope is that this study will be able to provide an overview of policy makers and other stakeholders in photographing the religious life of the community. He also hopes to enrich the treasures of the field of socio-religious studies in the field of research and development of science in general.

\section{Literature Review}

\section{Caring}

The word care has various meanings. Tronto (1993) defines care as the achievement of something outside of himself. Caring is also often associated with warmth, positive, meaningful, and relationship (Phillips, 2007). Swanson (1991) states that caring is a way to maintain relationships with others, where other people feel commitment and personal responsibility. Noddings (2002) states that when we care about other people, we will respond positively to what is needed by others and express it into an action. According to Bender (2003) caring is making ourselves related to other people and whatever happens to that person. People who put the needs and feelings of others ahead of their own interests are people who care. Caring people don't hurt other people's feelings. They always try to appreciate, do good, and make others happy. Many values are part of caring, such as kindness, generosity, care, help, and compassion (USU,2012: 25). Caring is also not something that is done because we expect something in return. May (in Leininger 1981) defines caring as a feeling that shows a relationship where we question the presence of others, there is a relationship of devotion too, even willing to suffer for the sake of others. Dedication, mattering, and concern are important elements in caring. Caring starts with feelings, but does not mean just feelings. Concern drives behavior to emerge as a manifestation of these feelings. When something happens, we are willing to give our energy, so that good and positive happens to the people we care about. Caring or care for feelings to change into behavior. These behaviors and feelings are of course based on thoughts. The feeling of caring is 
not thoughtless, but on the contrary it is also based on consideration. Leininger (1981) concluded that caring is a feeling directed to others, and that is what motivates and gives strength to act or take action, and affects life socially (University of Sumatra Utara. 2012: 26). Constructive and positive, by increasing the closeness and selfactualization of each other. Leininger (1981) suggested there are four stages of caring, attachment, assiduity, intimacy and confirmation. Each stage is achieved by fulfilling the task needs properly. Concern becomes dysfunctional or hampered, if one or more needs are not met. According to Boyatzis and McKee (2005), caring is a tangible form of empathy and concern. When we are open to others, we can face difficult times with creativity and courage. Empathy encourages us to develop relationships with other people. Empathy will emerge when we start our curiosity about other people and their experiences. Then that empathy will be translated into action. Caring is based on a desire to fully bond with others and to meet their needs. However, the best way to understand what caring is to see how it is practiced. Caring can also be defined as something that has three components, namely: 1 . Understanding and empathy for the feelings and experiences of others 2. Awareness of others 3.The ability to act on these feelings with attention and empathy.

According to Swanson (2000), he mentions that there are five important dimensions of caring. (1) Knowing, trying hard to understand events that have meaning in the lives of others. In this aspect, avoiding assumptions about events experienced by other people is very important, centering on the needs of others, making in-depth assessments, looking for verbal and non-verbal cues, and engaging in both cues. (2) Being present, being emotionally present by conveying availability, sharing feelings, and monitoring whether other people are disturbed or not with the emotions given. (3) Doing, doing something for others, such as doing it for oneself, whenever possible, such as comforting, protecting and prioritizing, such as performing tasks with full skill and ability while maintaining dignity. (4) Enabling, facilitating life journeys and unusual events that are owned by others by providing information, providing explanations, providing support, focusing on appropriate attention, and providing alternatives.
(5) Maintaining belief, supporting other people's belief in their ability to undergo events or transitional periods in their lives and face the future with meaning. This allows others to interpret and maintain a hopeful attitude. Caring of the Mosque Worshipers and the MUI Fatwa

On 21 Rajab $1441 \mathrm{H}$ to coincide with March 16, 2020, the Central MUI Leadership Council issued a Fatwa of the Indonesian Ulama Council Number 14 of 2020 concerning the Implementation of Worship in a Situation of a Covid-19 Outbreak.

The contents of the fatwa are as follows: (1) Every person is obliged to make efforts to maintain health and stay away from anything believed to cause him to be exposed to disease, because this is part of maintaining the main goal of religion (alDharuriyat al-Khams). (2) People who have been exposed to the Corona virus are obliged to protect and isolate themselves so that there is no transmission to other people. For him, the Friday prayer can be replaced with the midday prayer at his residence, because Friday prayer is a compulsory worship that involves many people so that there is a chance of mass transmission of the virus. For him, it is haram to carry out sunnahworship activities that open up opportunities for transmission, such as worshipers praying five times a day / rawatib, Tarawih and Eid prayers in mosques or other public places, as well as attending public recitation and tablighakbar. (3) People who are healthy and who have not been known or believed not to have been exposed to COVID-19, must pay attention to the following matters. (a) In the event that he is in an area where the potential for transmission is high or very high based on a decision by the competent authority, he may leave the Friday prayer and replace it with Zuhur prayer at his residence, and leave the worshipers of the five daily prayers / rawatib, Tarawih, and Ied in mosques or other public places. (b) In the event that he is in an area where the potential for transmission is low based on a decision by the competent authority, he is still obliged to carry out his obligations of worship as usual and must guard himself so as not to be exposed to the Corona virus, such as not having direct physical contact (shaking hands, hugging, kissing hands), bring your own prayer mat, and frequently wash your hands with soap. (4) In a condition where the spread of COVID-19 is 
uncontrolled in a life-threatening area, Muslims may not hold Friday prayers in that area, until things return to normal and are obliged to replace them with midday prayers in their respective places. Likewise, it is not permissible to organize worship activities that involve large numbers of people and are believed to be a medium for the spread of COVID-19, such as worshipers praying five times a day / rawatib, Tarawih and Eid prayers in mosques or other public places, as well as attending public recitation and majelistaklim. (5) If the spread of COVID-19 is under control, Muslims are obliged to hold Friday prayers. (6) The government has made this fatwa a guideline in efforts to tackle COVID-19 related to religious issues and Muslims are obliged to obey it. (7) The management of a body (tajhizjanazah) exposed to COVID-19, especially in bathing and shrouding, must be carried out in accordance with medical protocol and carried out by the competent authority, with due observance of the provisions of the Sharia. Meanwhile, praying and burying him is done as usual while keeping him from being exposed to COVID-19. (8) Muslims should get closer to Allah by increasing worship, repentance, istighfar, dhikr, reading QunutNazilah in every fardhu prayer, increasing prayers, increasing alms, and always praying to Allah SWT to be given protection and safety from calamity and distress. (prayerdaf'u al-bala '), especially from the COVID-19 outbreak. (9) Actions that cause panic and / or cause public harm, such as buying and hoarding basic necessities and hoarding legal masks is haram (Doc. Fatwa MUI No. 14 of 2020).

In this series of fatwa, the MUI also issued recommendations: (1) The government is obliged to impose strict restrictions on the entry and exit of people and goods to and from Indonesia, except for medical personnel and imports of basic necessities and emergency needs. (2). Muslims must support and obey government policies that isolate and treat people exposed to COVID-19, so that the spread of the virus can be prevented. And (3) The community should be proportional in responding to the spread of COVID-19 and people exposed to COVID-19 according to health principles. Therefore, the community is expected to receive back people who test negative and / or are declared cured.
Rusyana's article entitled Fatwa on the Implementation of Worship at the Covid-19 Pandemic in Indonesia and Egypt shows that scholars in Indonesia and Egypt have responded to the Covid-19 virus pandemic appropriately, namely by issuing fatwa's regulating the implementation of worship during the pandemic. By prioritizing prevention of kemafsadatan rather than taking on kemaslahatan (Rusyana, et al, 2020: 1). Meanwhile, another article, Mushodiq, Muhamad Agus and Imron Ali (2020) entitled The Role of the Indonesian Ulema Council in Mitigating the Covid-19 Pandemic: Overview of Social Action and the Domination of Max Weber's Power. The results of this paper are: First, MUI is an actor of social religious action. Second, the motives for MUI socio-religious actions through fatwa's issued contain three dominant motives. Third, the instrumentally rational motives in the fatwa refer to various models of worship. Fourth, MUI uses the values of the Islamic Religion which originate from the Qur'an, Hadith, and Jurisprudence. Fifth, MUI seeks to continue the traditions of the Prophets and Friends. Sixth, the MUI's Domination of Power determines the mandatory and unlawful matters in worship. Seventh, the MUI has a very important role in the mitigation effort of the COVID-19 Pandemic (Mushodiq, et al, 2020: 455 ).

This article is different from the two articles above, both of which reveal the efforts and responses of the MUI in preventing the spread of the Covid-19 Pandemic among Muslims. Meanwhile, this article seeks to answer the question of how the jamaah of mosque cares after the MUI issued a Fatwa in an effort to prevent Covid-19. The concern of mosque congregations referred to in this article is the realization of the MUI fatwa for mosque worshipers in worshiping during the pandemic era in the research area. The aspects studied are knowing, attending, doing, enabling and maintaining belief (Swason, 2000).

\section{Research Methods}

The data of this study came from research with a quantitative approach. The sample was determined using the quota purposive random sampling method, provided that the mosque worshipers was selected by the Jami mosque or village level mosque used for Friday prayers every 
week, the sample was randomly selected by worshipers around the mosque with the assumption that they were more aware and intense to follow the activities on the agenda of mosque administrator. Data collection was carried out in two or two stages. The initial stage was carried out to coordinate with various stakeholders and search for field officers who contributed to the field data collection. The implementation of this stage took place from 14 to 18 June 2020. Next, the data collection stage from field officers. This stage was carried out on 21 to 25 July 2020 . The data is then entered and then analyzed to be presented in the findings and discussion section.

Boja sub-district covers 18 villages/wards. Each village/sub-district was taken 1 jami mosque so that 18 mosques were selected as the data collection base. (BPS Kab. Kendal, 2019: 11). To determine the determinants of the mosque worshipers, the mosque population was taken from 10 villages that represented character, namely 5 villages with urban characteristics and 5 mosques in extreme rural areas. Urban villages include Boja, Tampingan, Bebengan, Meteseh and Salamsari villages. Meanwhile, the other 5 villages, Pasigitan, Medono, Leban, Banjarejo and Puguh, were included in the villages considering their location and condition.

The mosque worshipers who became respondents were obtained by the following calculation: The estimated number of active mosque worshipers is an average of 40 people so that the population is 400 worshipers. The Kirtji-Morgan table is used as the basis for taking a minimum sample of 196 respondents (UmmaSekaran, 2006: 159). In the study, there were 200 respondents who were sampled so that they more than met the minimum requirements.

The data was collected by filling out a questionnaire from the indicators of the caring of the mosque worshipers. The grids and awareness indicators are as follows:

Table 1. Indicators of Concern of the Mosque worshipers

\begin{tabular}{ll}
\hline Caring & Question Grid \\
\hline Knowing & No. $14 / 2020$ \\
& - The question is based on the MUI Fatwa \\
\hline Attend & - The question is based on the MUI Fatwa \\
& No. $14 / 2020$ \\
\hline To do & - \\
& No. $14 / 2020$ \\
\hline Possible & The question is based on the MUI Fatwa \\
& $-\quad$ The question is based on the MUI Fatwa \\
\hline Maintain Faith & No. $14 / 2020$
\end{tabular}

The completed questionnaires were then collected and processed quantitatively using the Excel application. Data analysis is in accordance with the instructions in MENPAN Decree Number KEP / 25 / M.PAN / 2/2004, so that it is

The grid is included in the research question items to be distributed to respondents at the research location. standardized nationally. (Doc. KepMenpan Number KEP / 25 / M.PAN / 2/2004), so that the following standards are obtained:

Table 2. Concern Level Conversion 


\begin{tabular}{lllll}
\hline No & Interval & Conversion interval & Quality Concern & Caring Performance \\
& & & & \\
\hline 1 & $1,00-1,75$ & $25-43,75$ & D & Does not matter \\
\hline 2 & $1,76-2,50$ & $43,76-62,50$ & C & careless \\
\hline 3 & $2,51-3,25$ & $62,51-81,25$ & B & care \\
\hline 4 & $3,26-4,00$ & $81,26-100$ & A & Very care
\end{tabular}

Source: Doc KepMenpan KEP/25/M.PAN/2/2004

(processed)

\section{Results and Discussion}

The results of this research data collection are presented in several sub-descriptions, namely descriptions of respondents' concern, descriptions of mosque worshipers caring and descriptions of determinants of concern for mosque worshipers in urban and rural areas.

\section{Respondent Description}

Determination of the gender of the respondent using a random method with the following results:

Table 3. Gender of Respondents

\begin{tabular}{cccccc}
\hline & & Frequency & Percent & Valid Percent & $\begin{array}{c}\text { Cumulative } \\
\text { Percent }\end{array}$ \\
\hline \multirow{3}{*}{ Valid } & Male & 113 & 56,5 & 56,5 & 56,5 \\
& Women & 87 & 43,5 & 43,5 & 100,0 \\
& Total & 200 & 100,0 & 100,0 & \\
\hline
\end{tabular}

Source: primary data (processed)

Male respondents were $56 \%$ and female respondents were $43 \%$. This similar percentage difference shows the equality of the mosque worshipers in a gender perspective. Respondents age can be seen in the following data:

Table 4. Age of Respondents

\begin{tabular}{|c|c|c|c|c|c|}
\hline \multicolumn{2}{|c|}{ Category } & Frequency & Percent & \multicolumn{2}{|c|}{$\begin{array}{r}\text { Valid Percent Cumulative } \\
\text { Percent }\end{array}$} \\
\hline \multirow{4}{*}{ Valid } & Youth (11-19) & 8 & 4,0 & 4,0 & 4,0 \\
\hline & Adult (20-60) & 178 & 89,0 & 89,0 & 93,0 \\
\hline & Elderly (>60) & 14 & 7,0 & 7,0 & 100,0 \\
\hline & Total & 200 & 100,0 & 100,0 & \\
\hline
\end{tabular}

Source: primary data (processed)

WHO has the following Age categories: Infants (infants) 0-1 years, Children (children) 2-10 years, Adolescents (adolescents) 11-19 years, Adults (adults): 20-60 years, and Elderly ( elderly) over 60 years (Karina Lestari and Harismi, 2020: 1).
The table above shows that most of the respondents are aged 20-60 years or adults as much as $89 \%$, then the second order is respondents with an age between $46-55$ years or adolescence by $4 \%$, and the three respondents 
with an age range of more than 60 or elderly year as much as $7 \%$. The education of the research respondents is shown in the following information display:

Table 5. Respondents Education

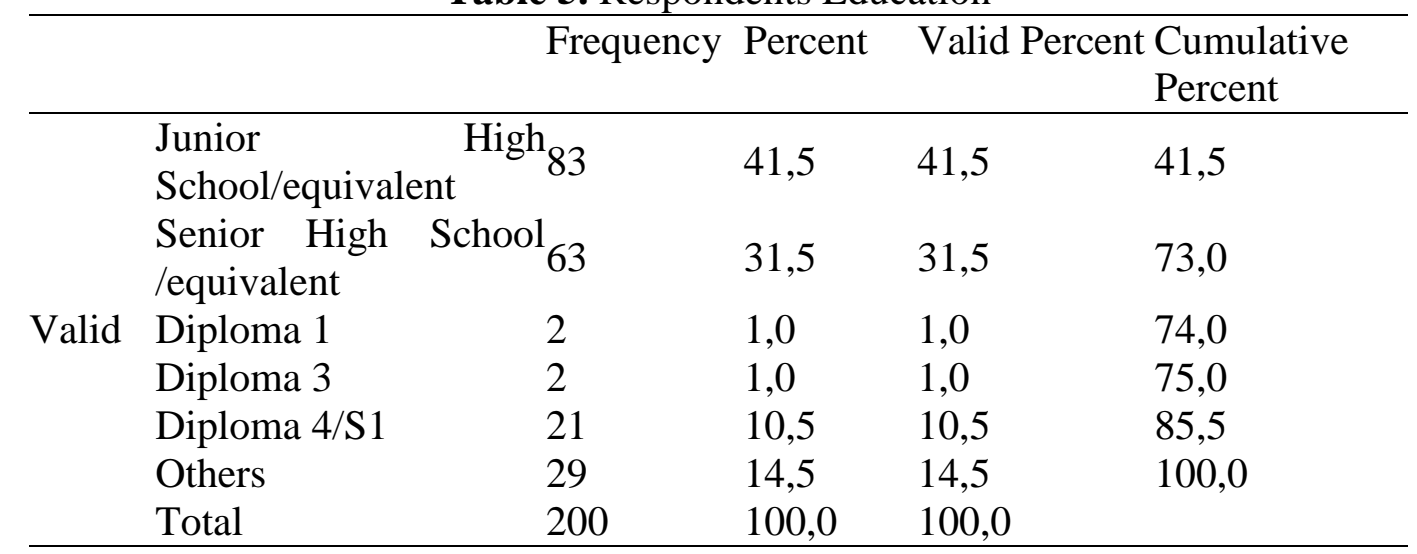

Source: primary data (processed)

Based on the information above, it can be seen that the education level of the most respondents is junior high school / equivalent as much as $41.5 \%$ and the second place is the respondent with a high school education level / equivalent as $31.5 \%$, others $10.5 \%$, D4 or S1 by $10.5 \%$ and the rest Diploma 1 and Diploma 3

Table 6. Position of Respondents

\begin{tabular}{lllll}
\hline & Frequency & Percent & \multicolumn{2}{c}{ Valid Percent Cumulative } \\
Percent
\end{tabular}

Source: primary data (processed)

The position of the respondents is that of worshipers and takmir or administrators. Most of the respondents were worshipers of 176 people $(88 \%)$ and the remaining $12 \%$ of respondents in the mosque became takmir or administrators.

\section{Description of the Caring of the Mosque worshipers}

The collected field research data is then processed using excel with the following results:

Table 7. Description of the Concern of the Mosque Congregation

\begin{tabular}{lllllll}
\hline No & Indicator & $\begin{array}{l}\text { Value } \\
\text { Standard }\end{array}$ & Standard & Value & Quality & $\begin{array}{l}\text { Level of } \\
\text { Concern }\end{array}$ \\
\hline 1 & Understand & 3,30 & 25 & 82,5 & A & Very care \\
\hline 2 & Feel & 3,30 & 25 & 82,5 & A & Very care \\
\hline 3 & Do Something & 3,17 & 25 & 79,25 & B & care \\
\hline 4 & Give support & 3,34 & 25 & 83,5 & A & Very care \\
\hline 5 & $\begin{array}{l}\text { Support the spirits } \\
\text { of others }\end{array}$ & 3,25 & 25 & 81,25 & B & care \\
\hline & Average & 3,27 & 25 & $\mathbf{8 1 , 7 5}$ & A & Very care \\
\hline
\end{tabular}

Source: primary data (processed)

Based on the conversion value above, the level of concern of the mosque congregation in Boja
Subdistrict, Kendal Regency, obtained a value of 81.75 with quality A, including in the Very Caring 
category, even though it is in the thin range of the category. The contribution of the caring aspect by doing something is the smallest compared to the others, namely 79, 25. Meanwhile, other aspects contribute to one another.

The results of this study illustrate that the caring of mosque worshipers in Boja District, Kendal Regency in responding to the MUI Fatwa No. 14 of 2020 in general is very care about the A value at point 81.75 . This figure is still not maximal in its range so it needs to get more encouragement from the stakeholders to increase it even higher.

\section{Description of the Determinants of the Caring of the Mosque Worshipers}

Boja is a sub-district bordering the city of Semarang to the north. As a buffer area for the capital city of Central Java, people's lives and the development of the region are also positively boosted. However, there are nuances that can still be seen between the villages located around the sub-district capital with the villages at the foot of the Ungaranmountain. The description of the results of field data collection is as follows:

Table 8. Description of Determinants of Caring of the Mosque Worshipers

\begin{tabular}{lllllll}
\hline No & Indicator & $\begin{array}{l}\text { Value } \\
\text { Standard }\end{array}$ & Standard & Value & Quality & Level of Concern \\
\hline 1 & Understand & 3,64 & 25 & 91,00 & A & Very Care \\
\hline 2 & Feel & 3,51 & 25 & 87,75 & A & Very Care \\
\hline 3 & Do Something & 3,52 & 25 & 88,00 & A & Very Care \\
\hline 4 & Give support & 3,49 & 25 & 87,25 & A & Very Care \\
\hline 5 & $\begin{array}{l}\text { Support the spirits of } \\
\text { others }\end{array}$ & 3,54 & 25 & 88,50 & A & Very Care \\
\hline & Average & 3,54 & 25 & $\mathbf{8 8 , 5 0}$ & A & Very Care \\
\hline
\end{tabular}

Source: primary data (processed)

Based on the conversion value above, the level of caring of urban mosque worshipers in Boja District, Kendal Regency, obtained a value of 88.50 with quality $\mathrm{A}$, including in the Very Carecategory. The contribution of the caring aspect by providing support was the smallest compared to the others, namely 87.25.
Meanwhile, other aspects contributed equally to the range of 87.00 to 88.00 . In fact, the understanding aspect of obtaining 91.00 points contributed the highest in the category of urban mosque worshipers members, namely Boja, Salamsari, Meteseh, Bebengan and Tampingan villages.

Table 9. Description of Determinants of Caring of Rural Mosque Worshipers

\begin{tabular}{lllllll}
\hline No & Indicator & $\begin{array}{l}\text { Value } \\
\text { Standard }\end{array}$ & Standard & Value & Quality & $\begin{array}{l}\text { Level } \\
\text { Concern }\end{array}$ \\
\hline 1 & Understand & 2,96 & 25 & 74,00 & $B$ & Care \\
\hline 2 & Feel & 3,09 & 25 & 77,25 & $B$ & Care \\
\hline 3 & Do Something & 2,81 & 25 & 70,25 & $B$ & Care \\
\hline 4 & Give support & 3,18 & 25 & 79,5 & $B$ & Care \\
\hline 5 & $\begin{array}{l}\text { Support the spirits of } \\
\text { others }\end{array}$ & 2,96 & 25 & 74,00 & $B$ & Care \\
\hline & Average & 3,00 & 25 & $\mathbf{7 5 , 0 0}$ & $B$ & Care \\
\hline
\end{tabular}

Source: primary data (processed)

The results of data processing show that the conversion value above means that the level of carinng of the worshipers of rural mosques in Boja District, Kendal Regency, gets a value of 75.00 with quality $\mathrm{B}$, including in the Care category. The contribution of the caring aspect by doing something is the smallest compared to the others, namely 70.25. Meanwhile, other aspects contributed in the range of 74.00 to 79.50 . Meanwhile, the aspect of providing support earned 79.50 points contributing the highest in the 
category of concern for rural mosque worshipers, namely Puguh, Leban, Medono, Pasigitan and Banjarejo villages, Boja District, Kendal Regency.

\section{Closing}

The results of field processing show some information as follows: (1) The level of concern of the mosque worshipers to the MUI Fatwa in preventing Covid-19 in Boja District, Kendal Regency is 3.27 points, with the title A included in the very caring criteria, (2) This figure is derived from of the 5 aspects of care, each aspect of understanding others is 3.30 (very good), the aspect of feeling is 3.30 (very good), the aspect of doing something for others is 3.17 (care), the aspect of providing support 3.34 (very care) and the aspect of Supporting the spirit of others by 3.25 (care), (3) the Determinant of Concern of the City Mosque worshipers at 3.54 (very care) and rural at 3.00 (care). The contribution of the aspect of understanding other people is urban by 3.64 (very care) and rural 2.96 (very care), the aspect of feeling also contributes 3.51 (very care) for urban and 3.09 (care) rural, the aspect of doing something for others, it scores 3.52 (very care) urban and 2.81 (care) rural, then the value is 3.49 (very care) urban and 3.18 (care) the aspect of providing support, and the aspect of supporting people's enthusiasm others show a value of 3.54 (very care) for urban areas and a value of 2.96 (care) for members of rural mosques, (4). 14 of 2020 in urban areas is higher than the worshipers of mosques in rural areas.

In general, the concern of the congregation of mosques in Boja sub-district, Kendal Regency, is in the "very care" category, but there are still things that need attention. Therefore, recommendations are made to help maintain the care of mosque worshipers, including: (1) To the officials of the Ministry of Religion and Religious Instructors to provide role models for the community in implementing fatwa of religious institutions so that they run effectively, (2) Religious / community leaders participate in providing role models for society in implementing tausyiah / fatwa of religious institutions in order to run effectively, and (3) Need synergy across policy stakeholders such as the Ministry of Religion and the Ministry of Home Affairs in educating the public to the lowest level.

\section{Thank-You Note}

This article is presented with the participation of various parties. For this, we would like to thank the Head of the Semarang Research and Development Center for Religion and his staff, the Head of the Ministry of Religion Office of Kendal Regency, the Head of KUA, Boja District, Religious Instructors (PAIF and PAH) in the Boja area, the Jami Mosque administrator and respondents in the village. Boja, Tampingan, Bebengan, Meteseh, Salamsari, Puguh, Pasigitan, Leban, Medono and Banjarejo villages. Also, thank you all who cannot be named one by one. Hopefully this article is useful and becomes a good deed for all, amen

\section{References}

[1] BPS Kabupaten Kendal, (2019). Kecamatan Boja Dalam Angka 2018. Kendal: BPS Kabupaten Kendal

[2] Dokumen Keputusan Presiden RI No. 11 Tahun 2020 tentang Penetapan Kedaruratan Kesehatan Masyarakat Corona Virus Disease 2019 (Covid- 19)

[3] Dokumen Keputusan Menteri Pendayagunaan Aparatur Sipil Negara No.KEP/25/M.PAN/2/2004 tentang Pedoman Umum Penyusunan Indeks Kepuasan Masyarakat Unit Pelayanan Instansi Pemerintah.

[4] Dokumen MajelisUlam Indonesia, Fatwa No. 14 Tahun 2020 Tentang Penyelenggaraan Ibadah Dalam Situasi Terjadi Wabah Covid 19

[5] Dokumen Keputusan Menteri Kesehatan Republik Indonesia Nomor Hk.01.07/Menkes/328/2020 Tentang Panduan Pencegahan Dan Pengendalian Corona Virus Disease 2019 (Covid-19) Di Tempat Kerja Perkantoran Dan Industri Dalam Mendukung Keberlangsungan Usaha Pada Situasi Pandemi

[6] itria Chusna Farisa dan Diamanty Meiliana, "UPDATE 26 Mei: Tambah 415, Pasien Covid-19 di Indonesia Jadi 23.165 
https://nasional.kompas.com/read/2020/05/ accessed on 27 May 2020

26/15584581/update-26-mei-tambah-415pasien-covid-19-di-indonesia-jadi-23165orang. , accessed on 27 May 2020

[7] Karina Lestari and Harismi, (2020). Risiko Penyakit Berdasarkan Klasifikasi Umur Menurut WHO https://www.sehatq.com/artikel/risikopenyakit-berdasarkan-klasifikasi-umurmenurut-who, accessed on 13 Agust 2020

[8] Mushodiq, Muhamad Agus and Imron , Ali, 2020. Peran Majelis Ulama Indonesia Dalam Mitigasi PandemiCovid-19; Tinjauan Tindakan Sosial dan Dominasi Kekuasaan Max Weber. Salam Jurnal Sosial \& Budaya , Vol 7 No. 5 (2020) page. 455-472. Semarang: Universitas Islam Negeri Walisongo Semarang . 10.15408/sjsbs.v7i5.15315

[9] Rusyana, Ayi Yunus and Supriyadi, Dedi and Khosim, Ali and Nugroho, Fahmi Hasan 2020. Fatwa penyelenggaraan ibadah di saat pandemi Covid-19 di Indonesia dan Mesir. Cirebon: Digital Library UIN Sunan Gunung Djati. (Unpublished), accessed on 0 October 2020

[10] Sugiyono, 2005. Statistik untuk Penelitian. Bandung: CV. Alfabeta .University of Sumatra Utara, (2012). http://repository.usu.ac.id/bitstream/handle /123456789/46282/Chapter\%20II;jsessioni $\mathrm{d}=\mathrm{C} 9 \mathrm{E} 3 \mathrm{~A} 0854 \mathrm{E} 5 \mathrm{~F} 3305822 \mathrm{E} 44 \mathrm{C} 8 \mathrm{C} 451 \mathrm{~B}$ 739 ? sequence $=4$, accessed on 5 September 2020

[11] Umma Sekaran, (20060. Metodologi Penelitian Untuk Bisnis, Jakarta: Empat, https://teorionline.files.wordpress.com/201 1/04/tabel-sampel-krejcie-dan-morgan.pdf, accessed on 12 June 2020

[12] ............https://news.detik.com/berita-jawatengah/d-5030015/update-corona-dijateng-27-mei-1379-positif-dan-732-pdpmeninggal, accessed on 27 May 2020

[13] .............https://www.antaranews.com/berit a/1462407/jubir-pemerintah-covid-19-jadibencana-nasional-karena-berdampak-luas, 